\title{
4. Kinship and Transnationalism
}

\author{
Cluny Macpherson and La'avasa Macpherson
}

\section{Introduction}

Kinship frames Samoan social organisation and Samoan transnationalism. It defines the matrix within which people, capital, ideas and technologies move between the nodes of 'transnational Samoa'. This matrix of relationships was the foundation of transnational Samoa: it provided the potential for a transnational Samoa, and the practices gave it form. Commitment to kin, expressed in visits and participation in ceremonials, gifts and exchanges, creates, maintains and reflects an active transnationalism. Without these regular and affirming exchanges there is no active transnationalism.

If kinship is, in effect, the foundation of transnational Samoa, then anything that transforms the character of kinship has the potential to reconfigure Samoan transnationalism. Anything that weakens kinship bonds between origin and overseas communities, which are the 'nodes' of transnational Samoa, has the potential to undermine it. Conversely, anything that strengthens those bonds ensures the survival of an active Samoan transnationalism. Therefore, any attempt to explain the condition of Samoan transnationalism must focus first on the conditions of kinship and the factors affecting it in any given node. This chapter argues that commitment to kinship is shifting in Samoan migrant enclaves as kin relationships are modified to meet the changing needs and circumstances of the migrants and their descendants (Macpherson and Macpherson 1999). These changes are transforming Samoan transnationalism.

This chapter outlines the role that kinship played in the establishment and maintenance of transnational Samoa, and the ways in which the transformation of kinship within migrant enclaves in New Zealand is now affecting the contours of Samoan transnationalism. First, we examine the connections between kinship and social organisation which evolved on small islands and their transformation in urban, industrial environments. Using material from a longitudinal study, we outline the form and significance of kin-based activity among new Samoan migrants in New Zealand in the 1950s. Then, we trace the expansion of kin-based activity in the 1950s and 1960s, its elaboration in the 1970s and early 1980s, and its contraction from the mid-1980s. We identify factors that have produced these shifts and conclude that the latest changes will weaken the commitment to kinship and may have profound consequences for transnational Samoa which it underpins. 


\section{Kinship in Samoan Society}

Samoan society evolved largely uninterrupted in the small, isolated but well-endowed group of islands for 3,500 years until the late $18^{\text {th }}$ century. The central feature of Samoan social organisation was kinship (Kramer 1994). Society consisted of clusters of localised, co-resident kin corporations or āiga. Rights over land and sea were vested in the various, usually related, äiga which lived in villages in an area (Gilson 1963). A chief, or matai, selected by senior members of the äiga, held the corporation's chiefly title and managed its resources on behalf and for the benefit of its members. Effective matai used the resources of their àiga to enhance its material and socio-political wealth; ineffective matai squandered äiga resources. At any time, the size and power of äiga varied according to the quality of leadership: well-led àiga attracted members and poorly-led ones tended to lose them (Macpherson 1997). Over time, certain áiga consolidated gains and came to control more land and to enjoy more permanent social prestige and political influence. This led to more or less fixed relations between aiga of villages and districts, and to the emergence of relatively stable local polities. ${ }^{1}$

Samoans had links with the äiga of four grandparents. Of these, the most significant were links with the äiga with which they resided at given time and which became their 'strong side' or itu malosi. For individuals, äiga membership established social location and significance, conferred rights to use agricultural land and a house site, and to protection by the aiga. These rights were offset by a number of parallel obligations, including the requirement to serve (tautua) one's matai, to protect the land and to defend the honour of the äiga. The rewards for service were a degree of psychological and material security, and, for males at least, the prospect of eventual leadership and power. ${ }^{2}$

\section{Kinship in Action}

Extended kin groups constituted the matrix within which goods and services were continuously exchanged in more or less public transactions. The least public involved the informal day-to-day exchange among relatives of goods such as money and food, services such as labour and advice, and equipment such as canoes and tools. The more public transactions involved the mobilisation of kin and resources in larger, formalised exchanges associated with commemoration of rites of passage, and physical and sociopolitical capital creation. Those who derived a livelihood from the use of the kin group's resources were bound to participate in both forms of activity. Participation was, in each case, underpinned by two related beliefs: that kinship confers upon one the obligation to give to kin who make legitimate requests, and the right to expect that at some time in the future the goods and services given to others will be returned. Both forms of exchange reproduce and reaffirm kinship and kin-groups. 
Exchanges are 'sites' where some discharge existing 'debts', and others incur new 'debts' to their kin. On a given occasion, persons $\mathrm{A}, \mathrm{X}$ and $\mathrm{Y}$ may discharge existing debts to person B by contributing to a wedding sponsored by B. On that same occasion, B may incur new debts to contributors D, E and F who also contribute, but who are under no obligation to participate and have no pre-existing debt to settle. The exchange process generates a residual indebtedness that binds kin over time. At any time, residual indebtedness within an äiga bound members to one another.

In other respects, the two forms of exchange have quite different outcomes for the reproduction and reaffirmation of kinship. Informal exchanges remind individuals of their dependence on kin for essential equipment, goods and services. Larger, formal mobilisations of kin group resources reaffirm the importance of cooperation among larger groups of kin, and of the sociopolitical benefits of active membership in a larger corporate entity. On these occasions, groups publicly demonstrate their ability to cooperate, to mobilise resources, and their right to public attention and respect from those both inside and outside of the aiga.

The isolation in which this form of social organisation evolved ended with the arrival of Europeans (Gilson 1970). But, despite the appearance of change, when Western Samoa won independence in 1962 after 130 years of exposure to European society, fundamental elements of Samoan social organisation remained largely intact. A monotheistic religion had replaced a polytheistic one and had been co-opted by Samoan society to bolster its traditions. A national polity, based on a modified Westminster system, had been created but was based on and existed alongside traditional polities, which continued to provide local government and to enjoy considerable autonomy. The leaders of the new state ${ }^{3}$ were chosen on the basis of traditional social status and the new parliament comprised matai ${ }^{4}$ elected by matai suffrage. 'New' social institutions, such as women's committees, existed alongside 'traditional' women's organisations within villages and promoted new initiatives, ${ }^{5}$ but did so with the consent and support of traditional village polities. Village mayors, pulenu'u, who were appointed by government to form a link between traditional polities and the national government, existed with the support of villages and remained under their control (Meleisea 1987).

Following independence, the non-monetised, subsistence economy was replaced by a monetised, mixed subsistence and cash cropping one that produced commodities for both local and international markets. However, this had occurred without significant transformation of either the land tenure system or the lineage mode of production. Most Samoans continued to live on and farm äiga land under the authority of matai and to contribute labour and part of their production as a form of rent to the matai, who used it on behalf of the aiga to enhance its 
socio-political status. As a consequence, kinship remained a fundamental principle of social and economic organisation in independent Samoa, albeit one changed by contact with capitalism (Macpherson and Macpherson 1999, 33). It would become the vehicle for the transnationalisation of Samoan society.

After independence, forces for rapid social change emerged both inside and outside Western Samoa. ${ }^{6}$ The most powerful force was developing beyond Samoa. Throughout the 1950s, New Zealand governments promoted industrialisation to diversify the country's economy. Labour shortages, a consequence of low pre-war population growth rates and losses in WWII, hindered the process, so to offset these, governments promoted immigration from Europe and the Pacific (Ongley 1991; 1996). People were drawn in increasing numbers from rural, semi-subsistence, kin-based villages in Samoa, the Cook Islands, Niue and the Tokelau Islands, to wage-work in socially and ethnically heterogeneous, urban industrial centres. Kinship became both the motive and the vehicle for transnationalisation of these societies.

\section{Foundations of Migrant Samoan Kinship}

It is difficult to imagine circumstances more likely to undermine a system of extended kinship based on common ownership of resources that had evolved in a small, rural village-based society. Yet, early studies of the migrants showed that kinship remained a central feature of migrant community organisation (Macpherson 1974; Pitt and Macpherson 1974). Kinship played a central role in Samoan transnationalism: chain migration, in which early migrants opened the way for later migrants from their families, produced Samoan enclaves in New Zealand and connected the nodes of transnational Samoan society. This raises the question of why extended kinship remained significant in the new environment.

Residential and occupational concentrations in the enclaves provided the critical masses of migrants in which central elements of a Samoan world-view and life-style were more likely to survive. Samoans became concentrated in a restricted range of occupations and in low-income residential areas in and around cities where economic growth and diversification was occurring (Ongley 1991; 1996). Concentration was also fostered by racism on the part of some 'gatekeepers' in the private housing market, concentrations of government-owned rental housing and by the tendency to cluster new, owner-occupied housing in tracts around city fringes.

New Zealand's immigration policy favoured less 'expensive', better 'educated', younger, single migrants. Families in Samoa also encouraged younger, single people who had demonstrated commitment to service (tautua) to their kin group to migrate in the belief that they would continue to acknowledge their membership of and obligations to their äiga, and would remit money and goods 
(Pitt and Macpherson 1974). Migrants who met the costs of sponsoring the migration of kin did so in order to bring others who would share the costs of supporting the non-migrant äiga and, therefore, also had good reason for identifying people committed to Samoan values and practices.

To ensure that new migrants remained committed to these, most were sent to live, at least initially, in households with relatives who had demonstrated continuing commitment to äiga. Many of these people were integrated into Samoan migrant communities and encouraged new migrants to associate with other Samoans (Pitt and Macpherson 1974). Pressure from household-heads and migrant peers combined to ensure that the new arrivals remained committed to tautua to family in the island (Macpherson 2002). The consequence was the rapid growth of socially 'traditional' Samoan populations in New Zealand cities in the 1960s (Pitt and Macpherson 1974).

Each of these elements ensured that kinship remained important and that most migrants remained connected to the villages and families from which they had migrated. This connectedness was reflected in the flow of people, ideas, money and resources between the origin and enclave communities which became transnational Samoa.

\section{Migrant Kinship: The Early Period}

In the early phase of Samoan settlement, kinship remained an important feature of migrant social organisation. Within enclaves, related individuals and households exchanged goods and services informally in the same ways as they had in Samoa. This pattern was a consequence of choice and familiarity, and of a lack of familiarity with the dominant society's organisation and institutions. Kinship remained a matrix within which goods, services and information were routinely exchanged. Daily, informal exchanges among migrant kin had much the same consequences as they had in Samoa: they reproduced dependence on kin, and a preference for dealing with relatives in a range of matters (Macpherson 1974).

In this early period, however, the second role of kin groups, the mobilisation of greater human and physical resources to commemorate life crises, or fa'alavelave, was more difficult to reproduce. Generally, there were too few members of aiga present able to fund the celebrations in ways considered appropriate. Young migrants were acutely aware of their lack of the cultural knowledge required to manage such events and of the absence of older people with the necessary competence. Lack of familiarity with air travel discouraged many older people, who were familiar with ceremonial and protocol, from travelling to New Zealand. Fine mats, or 'ie toga, a central element of these ceremonies, were not readily available in New Zealand. Finally, the absence of appropriate Samoan-owned or controlled venues for the celebration of such 
events and dominant group's reluctance to hire facilities to unknown migrants, made finding places in which to celebrate life crises difficult (Macpherson 1974). So, when migrant life crises occurred throughout the 1950s and early 1960s, celebrations were transferred to Samoa where the critical mass of most äiga remained and where the necessary personnel, expertise, venues and fine mats were readily available. There, they were performed by chiefs and elders of the aiga according to traditional protocols. Parties of kin moved between New Zealand and Samoa to ensure that members' achievements were appropriately commemorated and that the kin group demonstrated its ability to mobilise and its claim to recognition. These movements were central to the continuing connection between nodes of kin groups and to transnational Samoa.

In sum, expatriate āiga continued to exchange goods, services and information informally but were unable to carry out other more formal activities so important to the reproduction of commitment to kin groups: the periodic, public demonstration of a group's power and claims to recognition. The co-dependence of 'home' and 'migrant' nodes also necessitated the connections which underpinned emerging transnationalism. But this was about to change.

\section{The Elaboration of Migrant Kinship}

Between the mid-1960s and the mid-1980s, the New Zealand economy and the country's Samoan population both grew rapidly. Kinship was changing. Whereas formerly it had been primarily a matrix within which goods, information and services were exchanged informally and routinely, it was becoming the basis for the organisation of larger, more complex traditional events and for the celebration of new events. Several factors lay behind this transformation.

First, migrants who attended ceremonies in Samoa began to acquire the necessary cultural knowledge, skills and confidence to organise and manage them. Those returning from events in Samoa brought with them the fine mats given in recognition of their service to their families, which created a growing supply of a crucial element of the ceremonies. ${ }^{7}$ Second, as a consequence of continuing migration, expatriate äiga were growing and the critical masses necessary to fund and manage major celebrations were developing in New Zealand. These later migrants included chiefs ${ }^{8}$ with the necessary experience to manage life crises and migrants with the knowledge and desire to sponsor the events. Third, increasing familiarity with air travel led more older people to travel to events in New Zealand. Indeed, many older Samoans visited expatriate children and grandchildren during the summer and returned to Samoa at the onset of winter. Their presence meant more events could be held in New Zealand. Finally, Samoan church building, which began in the late 1960s and continues in the present, resulted in the creation of Samoan-owned and controlled buildings in centres of Samoan population concentration and provided venues for Samoan activities. 
This combination of factors transformed the organisation of migrant kinship over the next two decades.

The same principles were used to encourage expatriate members to participate in these events as in Samoa. These included appeals to their sense of pride in and responsibility to their äiga, and pointing to the indirect benefits of increasing the group's sociopolitical status in both New Zealand and Samoa. The same strategies were used to plan and manage the events. Leaders of the sub-lineages established the resource requirements of gatherings. The äiga was, typically, divided into traditional sub-sections, which were assigned responsibility for labour and resources. Leaders of each sub-section then became responsible for mobilising its resources for the occasion.

Extended kinship provided an ideal vehicle for organising and funding events that were beyond the capacity of individual households. Participation, now effectively voluntary, ${ }^{9}$ was underpinned by the same principles as it had been in Samoa: kinship conferred on one the obligation to give to kin who made legitimate requests and the right to expect that at some future time the goods and services given to kin would be returned. It also maintained a level of residual indebtedness within an äiga which bound members to one another over time.

The use of kin-based organisation to replicate these events had unanticipated social consequences. It periodically reaffirmed the significance and potential benefits of membership of extended kin groups. Participation in the events renewed bonds between äiga members who did not routinely meet and extended individuals' social networks. The celebration of these events, typically reserved for those with records of unstinting service to the aiga, reminded members of the benefits of active participation in its affairs. Effectively-managed events won kin groups sociopolitical prestige within the migrant community and in Samoa, and all benefited by association. Indeed, for the reproduction of extended kinship and kin-based social organisation, the events' latent functions were as important as their manifest ones.

In this period, these events were controlled by matai who followed protocols with which they were familiar and in both scale and form the events were largely replications of such events in Samoa. The complementary requirements of these events, cultural competences from the home community and labour and resources from the migrant community, underpinned transnationalism. But several factors were about to change this forever.

\section{The Emergence of 'Ceremonial Inflation'}

Continuous chain migration had made expatriate àiga larger and wealthier. Untitled migrants, who had by now become established, sought and claimed leadership roles within the enclave. They now had more disposable income and also had access, in many cases, to the income of their New Zealand-born children 
with which to back their claims. New migrants, who were generally firmly committed to a Samoan world-view and lifestyle, were also willing contributors to and participants in these events. This process was intensified because migration had transformed traditional limits on families' access to resources. Families which in Samoa had lesser titles and limited numbers of people and resources, were no longer constrained by these facts. Migrant families' resources were limited only by the numbers of wage-earners and the leaders' ability to mobilise their support. This provided both opportunity and incentive for some families to seek upward mobility by challenging larger, better-established ones in ways that would not have been possible in Samoa.

Perhaps the most significant factor, however, was the re-emergence of the competitive dynamic in migrant Samoan society. This was in large part a consequence of the growing number of matai whose role was to use resources to enhance a kin-group's sociopolitical status and of a growing pool of resources with which to work. As kin-groups sought to establish their claim to status and recognition in the migrant enclave through demonstrations of collective strength and ability to mobilise resources, a form of 'ceremonial inflation' occurred. This inflation manifested itself in two ways: a growth in the scale of these formal events and the creation of new ones.

\section{The Elaboration of Traditional Ceremonies}

Weddings, arguably the most frequent of the 'traditional' celebrations, ${ }^{10}$ serve as a useful illustration of the way in which these new dynamics transformed these events. Over 20 years, typical weddings became larger and more expensive. Guest lists grew from around 50 to 500 people. Wedding photos during the period reflect the growth of bridal parties from four to around 16. Small, family-catered celebrations held in church halls became large, commercially-catered events held first in reception lounges, then medium-priced hotels and finally, in the early 1980s, in the banquet halls of the city's most expensive hotels.

When there were no more exclusive venues to 'conquer', competition focused on more expensive menus, larger bridal parties, booking the most expensive Samoan bands and the elaboration of formal Samoan exchanges that went alongside the wedding. The role of kin moved from sewing, cooking and serving to the raising of money to purchase specialist services such as bridal gown making, limousine hire and videography of the event. Alongside the wedding formalities, were another set of 'traditional' activities based on the exchanges between the bride's and groom's families which provided further scope for elaboration.

New factors increased the size and social complexity of these events. In Samoa, guests and matai were typically from either the bride's or the groom's families 
and well-known to all involved, which meant that the necessary protocols could be planned with some confidence. In New Zealand, guests included workmates, fellow church-goers and unrelated friends, and it became increasingly difficult to plan for these. The uncertainty raised the possibility of denying unexpected guests due deference, and forced sponsoring families to raise more money to cover these possibilities to avoid appearing ignorant of Samoan etiquette.

As guest lists grew, so did the number of matai who attended the weddings in an 'unofficial' capacity. Each of these chiefs could claim the right to speak and could reasonably expect a gift for having contributed prestige to the event. Failure to provide appropriately generous gifts for all who claimed them left a family with a reputation for meanness or, worse still, for attempting to stage something for which they lacked the knowledge and resources. Families were forced to estimate how many might attend and to provide for the upper estimate or risk public embarrassment. There were not only more matai, but also more complex relations between those present, as social networks extended to include the increasing numbers of non-Samoans invited to weddings. The increasing number of European (Papalagi) guests attending raised questions of how they were to be integrated into ceremonial sequences and their presence acknowledged. Those controlling the events needed ever more skill to ensure that all who were entitled to either social deference or gifts were identified and acknowledged publicly.

The formal exchanges of gifts, which occurred between the bride's and groom's families at the conclusion of the ceremonies, also became more complex and more expensive. As the bride's and groom's families competed to acknowledge the importance of the other by conspicuous demonstrations of their own wealth, pressure for ever-more formal and more generous gifts grew. The numbers of fine mats, or 'ie toga, given by women's families at large weddings, grew from around 20 to over 2,000. The value of gifts of goods (oloa), usually food and money, given by grooms' families to brides' families also grew dramatically, as did the formality surrounding the exchanges.

Finally, gifts received by the representatives of the bride's and groom's äiga on these occasions had then to be redistributed among members of their äiga who had contributed to the wedding, as acknowledgment of their part in the proceedings. As the number of sub-lineages contributing grew, so too did the political complexity of redistribution. An un-diplomatic redistribution would mean that the family would have considerable difficulty securing support later from those whom they offended.

But despite the risks inherent in poor 'performances' on these occasions, àiga continued to mount larger, more complex weddings because the sociopolitical rewards of good performances were high. The same could be said of the growth 
of new kin-sponsored occasions which emerged in New Zealand over the period, and carried the same sociopolitical possibilities and risks.

\section{The Creation of New Ceremonies}

Graduation ceremonies, which began to occur in the 1960s and 1970s as Samoans started to graduate from New Zealand universities, illustrate this process. Graduation was of great significance and families sought to commemorate members' academic successes publicly, but because the only tertiary institutions in Samoa were theological colleges and training colleges which did not award degrees, there was no established protocol.

Early graduation ceremonies were small, informal and relatively unstructured events, held usually in homes or church halls, in which families and friends gathered, shared a meal, held a brief service of thanksgiving and made speeches in which graduates were commended for their efforts and thanked for bringing honour to the family, and younger members of the family were encouraged to emulate them. These were usually reserved for the celebration of university graduations.

But as matai and äiga sought new sites in which to demonstrate their growing human and material resources, graduations presented an opportunity to extend and formalise the ceremony. ${ }^{11}$ Families started to invite guests whom they wanted, ostensibly, ${ }^{12}$ to thank for contributions to graduates' success and the 'top table' came to include ministers of religion, Sunday School teachers, music teachers, university faculty, sports coaches, colleagues, members of parliament and so on. They too were increasingly invited to speak on the graduates' achievements and potential, and to congratulate the graduates and their families. In many cases, these speakers were given gifts, often fine mats and food, in recognition of their contributions both to the graduate's success and to the dignity of the celebration.

Increasing numbers of Samoan graduates from an ever-wider range of tertiary institutions and courses provided an increasing number of opportunities for the evolution and refinement of a protocol of sorts. Over time, an extended format started to emerge in which thanksgiving services were followed by formal meals, speeches by graduates and representatives from both sides of the graduate's family, dances, formal photographs and gift-giving. As with weddings, a competitive element led to pressure for larger, more elaborate and more expensive graduation ceremonies.

\section{The Limits to Growth}

By the mid-1980s, limits to expansion and elaboration were becoming apparent. The time, energy and resources required to meet the obligations of an expanding and increasingly active transnational kin group began to exceed the resources 
available to its overseas members. Servicing the growing demands of the kin group in different nodes was placing social and financial pressure on migrant members, on whom the burden fell most heavily. Some pressures were the consequence of expansion itself; others were the products of demographic and cultural factors, while still others were the result of a general economic contraction of the New Zealand economy. Each of these factors is treated separately here for analytical purposes.

As kin-sponsored events became larger, and the numbers of contributing relatives increased, so did the number and size of debts incurred on those occasions by those who sought to mobilise äiga. A new category of debts was created when friends and workmates from outside the aiga contributed to the events, generating still more debts which honour demanded be satisfied. Migrants encountered real problems as they attempted to repay existing social debts by contributing to more frequent and expensive ceremonies, sponsored by those to whom they were indebted. There was simply not enough time or resources to settle escalating debts within the migrant enclave, before even contemplating meeting kinship obligations in other nodes. Yet expectations, fuelled often by the mistaken impression that migrants were wealthier than they were, continued to grow. For a time, individuals borrowed from finance companies and took larger or more expensive home mortgages in order to meet short-term obligations. These practices created more serious longer-term problems by replacing existing debts, which honour demanded be repaid, with more expensive ones which the law demanded be repaid.

The situation of migrants was exacerbated by the contraction of the national economy between 1984 and the early 1990s (O'Brien and Wilkes 1993; Roper 1993). Heavy job losses occurred in industries in which Samoans had become concentrated (Statistics New Zealand 1995), as tariff protections were removed and companies were forced to close or to move offshore (Ongley 1991; 1996). This produced increases in Samoan unemployment rates from historical levels of less than one per cent in the 1960s and early 1970s to 22 per cent for men and 21 per cent for women by 1991. Significantly, long term unemployment increased from 28 per cent in 1988 to 54 per cent in 1995 (Statistics New Zealand 1997: 346). This was accompanied by a decrease in full-time and an increase in part-time employment (Krishnan, Schoeffel and Warren 1994).

The situation of migrants was made worse by the early 1990s by four factors. First, deregulation of the labour market and restructuring of labour relations led to the loss of union protection for many workers ${ }^{13}$ and to falls in real wages (Macpherson 1992; Statistics New Zealand 1997: 356-7). Second, the reduction of welfare benefit levels, on which Samoans were becoming increasingly dependent, placed further downward pressure on incomes. (Macpherson 1992). Third, the institution of a range of 'user pays' charges, only partly offset by 
reductions in direct taxation, placed further pressure on Samoan families' discretionary income. Finally, the numbers of children born to early migrants who were starting to graduate, marry and have children; the numbers of migrants' parents becoming ill and dying in the islands; and the numbers of migrants leaving the work force were all increasing. Along with the increase in the actual numbers of those people came an increase in the number of postponed demands on migrant income and time.

Migrants found it increasingly difficult to meet the postponed debts from declining incomes and find the time required to meet the costs of appropriate demonstrations of solidarity. The requirement that people take and present gifts in person required considerable amounts of time and expense in travel. In a period when conditions of work were tightening and the labour market was contracting, the real costs of time off work were becoming higher.

These factors produced a situation in which the numbers of debts being incurred by mobilisation of the extended kin group were increasing rapidly just as resources available to settle these were contracting very quickly. Failure to meet due debts led to embarrassment, ma, and humiliation, masiasi, and made people increasingly reluctant to incur debts which they would be unable to repay, for, as Samoans declare somewhat starkly, ua sili le oti $i$ lo le masiasi, death is preferable to humiliation. This growing pressure was to have significant impacts on both kinship and the transnationalism which it underpinned.

\section{Kinship and Transnationalism}

More migrants began reviewing the costs and benefits of various forms of äiga participation as their circumstances changed and they were forced to choose between meeting the respective needs of their immediate and extended families and churches in both New Zealand and Samoa. ${ }^{14}$ They became cautious about mobilising their extended äiga and incurring new debts when this prevented them from meeting the steadily increasing needs of their immediate families. Some families limited the range of people whom they would support in order to avoid the costs associated with support for all who were recognised as kin. Other families set limits on the level of their support for people on the basis of their relationships in an attempt to limit outgoings of time and money on ceremonial events. Some congregations, concerned about the escalation of ceremonial costs, acted in concert to standardise contributions to various events in order to eliminate competition and control costs within the parish. ${ }^{15}$

More significant for Samoan transnationalism was the re-evaluation of the costs and benefits of supporting the expanding aspirations of home communities. Migrants found themselves under increasing pressure from parents and siblings to support a wave of new and often expensive building projects, rites of passage and political ambitions in the 'home' community. Some were simply unable to 
afford these and even those who could were not always willing to do so. Increasingly, migrants sought to manage their obligations to these projects at home. One compromise, which seems to be increasing popular, fundamentally altered the character of transnational linkages. It involved a de facto division of responsibility: migrants performed the obligations of kinship in the expatriate enclaves, while non-migrants attended to the obligations of kinship in the village. This arrangement worked well because those in each node were aware of the context and best placed to respond more quickly to demands, but it reduced the numbers of 'transactions' between expatriate and village nodes of kin groups.

Even if this crisis had not occurred, other factors might have constrained the elaboration of kin-based activity in the migrant community. Increasing levels of intermarriage, particularly with more individualistic Europeans, created limits to participation. With approximately one-in-three Samoans marrying non-Samoans, increasing numbers of people found themselves at odds with non-Samoan spouses over the value of supporting extended family. While Samoan spouses may wish to contribute to events within their extended families, European spouses, for a variety of reasons, frequently do not. This has had more serious consequences in some households than in others, notably those in which only one spouse is employed and incomes are limited. This has resulted in some cases in a total 'ban' on contributions of time and money, and in others a limit to the level of participation. Where the latter has occurred, some Samoan spouses have decided that it is better not to attend at all, than to attend and make a contribution smaller than might be considered appropriate.

The growth of support for new religious denominations such as the Seventh Day Adventist Church and the Church of Jesus Christ of Latter Day Saints within the migrant enclave may be both a cause and a consequence of the decline in ceremonial events. Adherents of these denominations are discouraged from sponsoring large-scale kin-based events and encouraged instead to focus their energy and resources on immediate family and church. Thus one finds, increasingly, apologetic riders to death notices advising readers that Samoan customs will not be observed on these occasions. ${ }^{16}$ At the same time, this practice may be encouraging people to join these denominations because membership provides a convenient and religiously sanctioned basis for limiting engagement and liability.

More significant for Samoan transnationalism is the declining commitment to àiga among overseas-born Samoans. New Zealand-born Samoans, raised in very different circumstances, often view kinship obligations differently from their parents. This is not to suggest that they have withdrawn support for these kin-based events. Anae's work on New Zealand-born Samoans show that many remain actively engaged in the whole range of activities (Anae 1997; 1998; 2001), but there is evidence that a significant group are choosing a lower level of 
engagement than their parents (Macpherson 1984), sometimes with the encouragement of their parents (Macpherson 1991).

The inter-generational difference stems from social values stressed in formal education; higher levels of formal education and greater economic and job security; changing composition of social networks and reference groups; high levels of intermarriage; changing patterns of religious affiliation; the emergence of new forms of ethnic identity; and critical reflection on the costs and benefits of participation in the full range of extended kin-based activities in both 'enclave' and 'island' (Macpherson 2002).

While many New Zealand-born Samoans continue to participate in extended kin group activities they do so at the request of and out of a sense of responsibility to their parents (Anae 1998). Their participation is in many cases indirect, either because of lack of language competence and familiarity with ceremonial forms, or because demands of work prevent or discourage their direct involvement. Whether their participation will continue after their parents' death is a matter for conjecture. These people, however, continue to value and to exchange information and services, and to spend leisure time with family in New Zealand. However, they do this voluntarily and typically within smaller circles of kin than their parents felt compelled to recognise, and do so on the basis of personal friendship rather than a sense of obligation (Macpherson and Macpherson 1999).

While New Zealand-born Samoans typically maintain personal connections with their a aiga in the enclave, many have had little to do with their relations in Samoa. They report lower levels of commitment to äiga whom, in many cases, they have not met, and to villages in which they have neither lived nor visited. Even those who report some general commitment to relatives in the island, tend to rank this behind their commitments to their äiga in the enclave and recognise the latter only when asked to do so by parents. Many find that increasing difficulty in communicating in Samoan and diverging experiences and aspirations create increasing social distance between them and their Samoan äiga. If this process continues, there will be less contact and fewer transactions between island-based and expatriate kin, which in turn will have significant effects for the character of transnational Samoa.

\section{Conclusion}

At the heart of Samoan transnationalism is kinship or äiga which generates the matrix of relationships that extend across national boundaries and form the conduits along which cash, goods and ideas flow. Extended kinship is alive and well in Samoa because it remains crucial to access to land and marine resources, chiefly titles and socio-political status. However, an active and ongoing transnationalism requires an active commitment on the part of kin living abroad to the practices which give transnationalism form. 
In expatriate Samoan communities in New Zealand, social and economic factors have reduced the numbers, scale and complexity of occasions for which the extended family is mobilised within the enclave. This in turn has attenuated the competitive pressures that drove social inflation during the 1970s and early 1980s. As economic times got harder for the less-skilled through the late '80s and '90s, the primary role of the äiga-a social matrix within which informal exchanges of goods and services occurs, providing some protection from harsh realities of life on the edge of a volatile economy - again became increasingly important. In this respect the role of äiga among migrants can be said to have almost turned full circle in the last 35 years.

The emergence of increasingly organised Samoan communities in overseas nodes, with comprehensive ranges of social activity, may localise the focus of much kin exchange and mobilisation within these increasingly autonomous nodes. The growing influence of people born and raised in these nodes may lead to declining support for activities in 'home' communities to which their ties are increasingly attenuated. The declining density of direct relations and number of transactions between nodes may undermine the foundations of transnational Samoa. The recently increased migration flows from Samoa (Bedford, 2007) may renew transnational ties and slow the decline, but are unlikely to reverse the declining number and strength of linkages between 'overseas' and 'home' nodes over the longer term.

These shifts in äiga organisation in the enclave may, in turn, influence the ways in which kinship is organised in Samoa for, as noted at the outset, migrant enclaves do not constitute discrete, distant communities but rather sites in which modification and experimentation are legitimated by the necessity of finding Samoan solutions to new social, economic and political realities. Those modifications that seem to meet new needs can find their way back into Samoan 'traditional' forms, and in the social space between these two settlements a meta-culture emerges which is neither a 'migrant' nor a 'traditional' culture but a contemporary Samoan one.

\section{References}

Anae, M. 1997. Towards a New Zealand-born Samoan identity: Some reflections on 'labels'. Pacific Health Dialog, 4 (2): 128-37.

—. 1998. Fofoa i vaoese: Identity journeys of New Zealand-born Samoans. PhD Thesis, University of Auckland, NZ.

—. 2001. The new 'Vikings of the Sunrise': New Zealand-borns in the information age. In Tangata o te Moana nui: The evolving identities of Pacific peoples in Aotearoa/New Zealand, ed. C. Macpherson, P. Spoonley, and M. Anae, 101-21. Palmerston North: Dunmore Press. 
Bedford, R. D. 2007. Pasifika mobility: Pathways, circuits and challenges in the 21 st century. Institute of Policy Studies, Victoria University of Wellington. Wellington.

Gilson, R. P. 1963. Samoan descent groups: A structural outline. Journal of the Polynesian Society, 72: 372-77.

—. 1970. Samoa 1830-1900. The politics of a multi-cultural community. Melbourne: Oxford University Press.

Kramer, A. 1994. The Samoa Islands. Auckland: The Polynesian Press.

Krishnan, V., P. Schoeffel, and J. Warren. 1994. The challenge of change: Pacific Island communities in New Zealand 1986-1993. Wellington: NZISRD.

Macpherson, C. 1974. Toward an explanation of the persistence of extended kinship among Samoan migrants in urban New Zealand. PhD Thesis, University of Waikato, NZ.

- 1984. Samoan Ethnicity. In Tauiwi: Racism and ethnicity in Aotearoa/New Zealand, ed. P. Spoonley, C. Macpherson, D. Pearson, and C. Sedgwick, 107-27. Palmerston North: Dunmore Press.

- 1991. The changing contours of Samoan ethnicity. In Nga Take. Ethnic relations and racism in Aotearoa/New Zealand, ed. P. Spoonley,

D. Pearson, and C. Macpherson, 67-86. Palmerston North: Dunmore Press.

- 1992. Economic and political restructuring and the sustainability of migrant remittances. The Contemporary Pacific, 4 (1): 109-35.

- 1997. The persistence of chiefly authority in Western Samoa. In Chiefs today: Traditional Pacific leadership and the postcolonial state, ed. G. M. White and L. L. Lindstrom, 19-49. Stanford: Stanford University Press.

- 2002. From moral community to moral communities: The foundations of migrant social solidarity among Samoans in Aotearoa New Zealand. Pacific Studies, 25 (1 \& 2): 71-93.

Macpherson, C. and L. Macpherson. 1999. The changing contours of migrant Samoan kinship. In Small worlds global lives: Islands and migration, ed. R. King and J. Connell, 277-91. London: Pinter.

Meleisea, M. 1987. The making of modern Samoa. Suva: Institute of Pacific Studies, USP.

O'Brien, M. and C. Wilkes. 1993. The tragedy of the market: A social experiment in New Zealand. Palmerston North: The Dunmore Press.

Ongley, P. 1991. Pacific Islands migration and the NZ Labour Market. In Nga Take: Ethnic relations and racism in Aotearoa/New Zealand, ed. 
P. Spoonley, D. Pearson, and C. Macpherson, 17-36. Palmerston North: Dunmore Press.

- 1996. Immigration, employment and ethnic relations. In Nga Patai. Racism and ethnic relations in Aotearoa/New Zealand, ed. P. Spoonley, D. Pearson, and C. Macpherson, 13-34. Palmerston North: Dunmore Press.

Pitt, D. and C. Macpherson. 1974. Emerging pluralism: The Samoan community in New Zealand. Auckland: Longman Paul.

Roper, B. 1993. The end of the golden weather. In State and economy in New Zealand, ed. B. Roper and C. Rudd. Auckland: Oxford University Press.

Statistics New Zealand. 1995. Samoan people in New Zealand. A statistical profile. Wellington: Statistics New Zealand.

—. 1997. New Zealand official yearbook 1997. Wellington: GP Publications.

\section{ENDNOTES}

1 The relative status of all äiga within local polities was embodied in formal statements known as fa'alupega which were recited periodically and publicly.

2 While nothing prevented women from holding power and in fact women were immensely important, in practice men held most matai titles.

3 The joint Heads of State and the Council of Deputies.

4 Two seats in the new Parliament were reserved for 'individual voters' who did not have to hold matai titles.

${ }^{5}$ The traditional organisations were the wives of chiefs and orators, faletua ma tausi, and the association of village women, aualuma, which comprised women born in the village but not in-marrying women.

6 In 1997, the constitution was revised to change the country's name from Western Samoa to Samoa.

7 Only a small pool was necessary because they were in constant circulation and because during this time only relatively small numbers were being exchanged at any ceremony.

8 More chiefly titles were created after 1962 and more holders were appointed to existing titles as a result of changes in electoral legislation; new chiefs were not necessarily concerned with day-to-day aiga management and were able to work overseas.

9 Because migrants' livelihoods were no longer derived directly from the use of land or sea vested in the äiga, they were no longer legally bound by the authority of the matai.

10 'Traditional' because, while prominent unions have always been marked with much ceremony, less prominent people's unions have not and because the form is a Samoanised version of a Christian ceremony.

11 Some graduates who had discouraged families from spending large amounts of money and who had resisted the increasing formality and ceremony had been reminded that this was an occasion for the family!

12 A number of graduates noted that these occasions gave their parents an opportunity to show friends, family and guests 'how many important people they knew'.

13 Between 1991 and 1995, union membership fell from 514,325 to 362,200 and coverage from 35.4 per cent to 21.7 per cent (Statistics New Zealand 1997) and tended to be strongest in highly-skilled and organised sectors. Those sectors in which many migrants were engaged were reorganised and significant numbers of jobs either disappeared or were casualised and effectively de-unionised.

14 Over time, churches founded on the Samoan organisational model have become thoroughly established in New Zealand. These mainstream Samoans denominations include the Congregational Christian Church of Samoa (Ekalesia Fa'apotopotoga Kerisiano Samoa), the Methodist Church (Le Lotu Toga) and the Roman Catholic Church have become the most popular among Samoan church-goers. These congregations meet their pastors' living costs, pay their stipends and erect church buildings. The combined effect of these commitments on time and income are great and ongoing, particularly in smaller congregations. 
15 I am indebted to Galumalemana Alfred Hunkin-Tuiletufuga, for a description of how Catholic parishes in New Zealand have formulated procedures to achieve this end.

16 This generally appears as 'Fa'maolemole, taofi le malo' or more bluntly, 'Please, no fine mats' or 'No fa' asamoa'. Of course these injunctions are at best only partially successful, since many people feel unable or unwilling to attend funerary rites without taking a gift, for fear of encountering others with gifts. 